\title{
Management Planning and Implementation of the Scholarship Program 5000 Doctor of UIN Sunan Ampel Surabaya
}

\author{
Saridudin \\ \{dudinsaridudin@gmail.com\} \\ Center for Religious and Religious Education \\ Religious Research, Development and Training Agency, Ministry of Religious Affairs
}

\begin{abstract}
This study aims to describe management planning and implementation of the 5000 doctor Scholarship program for the Ministry of Religion at State Islamic University of Sunan Ampel Surabaya. The method used in this study is qualitative. The results showed that the 5000 doctoral program scholarship planning management at State Islamic University of Sunan Ampel Surabaya had not yet proceeded according to the desired plan, because there were still many students who had not graduated according to the desired target, namely three years or 6 semesters. In terms of implementation, this scholarship program is in great demand by lecturers who teach at Private Islamic Universities, it is not an attractive magnet for lecturers who teach at State Islamic Universities. Postgraduate of State Islamic University of Sunan Ampel Surabaya has a superior Doctoral program namely Dirasah Islamiyah or Islamic Studies which develops Islamic studies with interdisciplinary approaches and social theories with an emphasis on contemporary issues such as human rights, gender, and democracy. This study recommends that the Ministry of Religion need to make special efforts so that this scholarship program is in great demand by lecturers not only from Private Islamic Religious Colleges but from State Islamic Religious Colleges. The strategy, for example, is to allow Civil Servants to take part in scholarship programs, taking into account their income from scholarships is not smaller than the basic salary, performance allowances and other benefits they receive daily.
\end{abstract}

Keywords: Management, Planning, Implementation, 5000 Doctor Scholarship.

\section{Introduction}

IAIN Sunan Ampel was established in 1965 through the Decree of the Minister of Religion Number 20/1965. At the beginning of the establishment of IAIN Sunan Ampel had 18 faculties spread across 3 provinces namely East Java, East Kalimantan, and West Nusa Tenggara. Since mid-1997, through Presidential Decree No. 11 of 1997, all faculties under the auspices of IAIN Sunan Ampel outside Surabaya were released from IAIN Sunan Ampel to become an autonomous State Islamic College (STAIN).

IAIN Sunan Ampel has since been concentrated only on 5 faculties, all of which are located on the campus of J1. A. Yani 117 Surabaya. Starting from October 1, 2013, IAIN Sunan Ampel changed to the State Islamic University of Sunan Ampel (UINSA) Surabaya based on Republic of Indonesia's Presidential Decree No. 65 of 2013. Currently, UIN Sunan 
Ampel Surabaya has 9 faculties undergraduate and postgraduate, and 44 study programs (33 undergraduate programs, 10 master programs, and 4 doctorates). Postgraduate of UIN Sunan Ampel Surabaya was established in 1994 through the Decree of the Minister of Religion No. 286 of 1994, concerning permission for the organizer of the Dirasah Islamiyah Postgraduate Study Program (S2) on August 1, 1994.

As for the Doctoral program, it was confirmed in the Decree of the Director-General of Islamic Institution of the Ministry of Religion of the Republic of Indonesia No.E / 250 of 2001 concerning the permission of the Dirasah Islamiyah Postgraduate Doctoral Study Program organizer on September 26, 2001. The aim of the Doctoral Program at UIN Sunan Ampel Surabaya was to produce Muslim scholars those who believe and fear Allah SWT, have the spirit of Pancasila, have high scientific integrity, are open, responsive to change, progress and development of science and problems faced by society, especially those related to the field of Islamic sciences. As an expert in the field of Islamic sciences who can become research personnel in the field of science. Having intellectual and moral integrity by the profession in the field of Islamic studies. Has methodological abilities in carrying out Islamic studies, and can understand and analyze socio-religious phenomena that develop in society.

Currently, UIN Sunan Ampel Surabaya has four doctoral programs namely Islamic Education, Al-Qur'an and Interpretation, Sharia Economics, and Doctor of Islamic Studies. The flagship program for Doctoral (S3) programs is Islamic Studies Study Program. Based on the Decree of BAN-PT No. 006 / SK / BAN-PT / Accredited / D / I / 2014 dated 09 January 2014, Doctoral Program in Islamic Sciences UIN Sunan Ampel Surabaya is accredited with Accreditation B.

Since the 2015/2016 Academic year, UIN Sunan Ampel Surabaya held classes for the 5000 doctoral Program Scholarship. Until 2018, 129 students participated in the program with details, in 2015 there were 29 people, 2016 as many as 36 people, in 2017 as many as 42 people and in 2018 as many as 22 people. Of the 129 numbers recorded for the 2015 class, only 3 were graduated, even though the design of the deadline planning provided by the Ministry of Religion was only 3 years or 6 semesters. This means that since they entered in the 7 th semester they no longer receive scholarships but must complete at their own expense. Under these conditions is it possible to give an additional period of study beyond 3 years.

Since the 2015/2016 Academic Year, UIN Sunan Ampel Surabaya held classes for the 5000 doctoral Program Scholarship. Until 2018, there are 129 students participated in the program with details, in 2015 there were 29 people, 2016 as many as 36 people, in 2017 as many as 42 people and in 2018 as many as 22 people. Of the 129 numbers recorded for the 2015 class, only 3 were graduated, even though the design of the deadline planning provided by the Ministry of Religion was only 3 years or 6 semesters. This means that since they entered in the 7th semester they no longer receive scholarships but must complete at their own expense. Under these conditions is it possible to give an additional period of study beyond 3 years.

In terms of management implementation, the 5000 doctoral scholarship program at UIN Sunan Ampel Surabaya can be explained, first, the 5,000 doctoral scholarship program at UIN Sunan Ampel Surabaya is more in demand by lecturers who teach in Private Islamic Higher Education, Second, Components, procedures, allocation, and the disbursement of the Five Thousand Doctoral scholarship program at UIN Sunan Ampel Surabaya with student acceptance of Rp. 4,000,000, - per month with the allotment of living costs, books, domicile, and research felt still inadequate not comparable to the needs of S3 students with various needs. 
Third, the doctor which is most needed at this time at UIN Sunan Ampel Surabaya is the Doctor of Sharia Economics. For now, four lecturers at UIN Sunan Ampel Surabaya take S3 study programs in Islamic Economics, namely Abdul Hakim, Lilik Rahmawati, Fatikul Himami, and Siti Musfiqoh. Of the four people who took the five thousand doctoral scholarship program, only one person, namely Siti Musfiqoh, a class of 2015 student.

This paper describes the management of the planning and implementation of a 5000 doctoral scholarship program at UIN Sunan Ampel Surabaya. Planning and implementation are considered important because to measure whether there is a match between the planned Ministry of Religion and the implementation that occurred at UIN Sunan Ampel Surabaya. The results of this study are expected to be useful as input to the Directorate General of Islamic Education, especially the Directorate of Islamic Higher Education in taking appropriate policies related to the management of the planning and implementation of 5000 doctoral scholarships in the future.

\subsection{Management concept}

The meaning of management regarding language originates from English which is an immediate interpretation of the word the board which means the executives, the board, or administration. While in the English Indonesian lexicon, the word the executives originate from the base of the word to oversee which means dealing with, controlling, actualizing, overseeing, and treating [2]. The management is the way toward organizing work exercises so they can be finished proficiently and successfully with and through others [4]. Sondang P. Siagian characterizes the management as the capacity or expertise to get a result to accomplish objectives through the exercises of others[ 5].

The general management capacity as indicated by Robbin and Coulter is the most significant arrangement, sorting out, driving, and controlling[4]. In accordance with that Mahdi container, Ibrahim expressed that administration capacities or initiative assignments in its execution incorporate different things, in particular, arranging, sorting out, coordinating and controlling [3].

Alluding to a portion of the above management understandings, it tends to be inferred that administration is a procedure of using all assets through the assistance of other individuals and working together with them so the objectives set can be accomplished successfully and proficiently.

Talking about management issues unquestionably can't be isolated from the four fundamental parts, to be specific Planning, Organizing out, Actuating and Controlling (POAC). In this paper, the creator will talk about two administration capacities, to be specific arranging (planing) and usage (Actuating).

\subsection{Planning}

The word planning is a general term that is very broad in the scope of its activities. Planning is a decision-making process for preparing a plan. The experts define the word planning with different sentences, depending on what aspects are emphasized. Planning is an arrangement of steps systematically or regularly to achieve goals or solve problems, can be in the form of graphics or visuals or pictures of buildings and their environment or can also be verbal in the form of a series of words. Planning is defined as an effort to utilize available resources by taking into account all limitations in order to achieve goals efficiently and effectively [7]. Planning is the first management function that must be carried out by every 
manager and staff. To be able to arrange good planning, analytical and conceptual thinking is needed.

The goals of planning in management consist of the following:

1. Planning public policy, namely the things that will be discussed in public policy planning, how to formulate public policy, choose a planning approach, political views and their role in planning, legal aspects, and funding planning.

2. Organizational planning and program planning activities of the managing organization. While the planning of the activities of organizational units in carrying out management is a program of activity plans for each organizational unit.

However, it can be concluded that in planning includes two meanings, namely determining in advance what will be done and Determination of a series of activities to achieve the desired results. In management science, planning is the earliest part of other management functions. The plan is a product of the planning process that is intended to achieve a certain goal through the stages of activity.

\subsection{Actuating}

Actuating is work, or efforts to realize the objectives of the plan that has been made or prepared. George R. Terry [1] argues that actuating is an effort to move group members in such a way that they are desirous and trying to achieve the company's goals and objectives of the company members because the members also want to achieve these goals. From this understanding, it is clear that actuating is nothing but an effort to make planning a reality, through various directives and motivations so that each employee can carry out activities optimally by their roles, duties, and responsibilities. The important thing to note in this actuating is that an employee will be motivated to do something if he feels confident he will be able to do it, confident that the work will benefit him, not being burdened by personal problems or other more important tasks, or urges, and the task is a trust for the person concerned.

The actuating function emphasizes more on activities that relate directly to people in the organization. Good planning and organizing is less meaningful if it is not followed by mobilizing all potential human and non-human resources in carrying out the task. All existing human resources must be optimized to achieve the vision, mission and work program of the organization. Every HR must work in accordance with the duties, functions and roles, expertise and competencies of each HR to achieve the organization's vision, mission and work program.

\section{Research methodology}

This research uses a qualitative approach. Qualitative research is research based on the philosophy of post-positivism, used to examine the conditions of natural objects, where researchers as key instruments, data collection techniques are carried out by triangulation, data analysis is inductive, and the results emphasize the meaning rather than generalization[6]. The study was conducted at the Postgraduate Program of UIN Sunan Ampel Surabaya, East Java.

The main instrument in this study is the researcher himself (human instrument). In this study, the sample data source was selected purposively and snowball sampling. The sample data source at the initial stage of entering the field is chosen by people who have the power 
and authority in the social situation or the object under study. In taking the sample, researchers are guided by the opinion of Spradley in Sanafiah Faisal (1990), namely, (1) Those who master or understand something through the process of enculturation, so that something is not just known, but also known, (2) Those who are classified as still being involved or involved in activities being investigated, (3) Those who have adequate time to be asked for information, (4) Those who are not inclined to submit their own packaging information, (5) Those who are initially unfamiliar with researchers so that it is more exciting to be a kind of teacher or resource.

Data collection is carried out by observing each activity and of course from the results of interviews with the informant. Data sources of this research are primary and secondary data sources. Primary data sources are the Postgraduate Director, Deputy Director, Student program takers and administrators. Whereas the secondary data source is supporting the organizer. The main data sources are recorded through written records or video/audiotape recording, taking photographs and films. As for additional data, researchers look for and document various data from other sources in order to enrich the data, both through books, photos, articles, newspapers, statistical data, and so forth.

In this study, researchers used data collection techniques that included observation, interviews, documentation and literature study. Because in this study using the method of observation, interviews, and documentation, the instruments needed include observation guidelines, interview guidelines. In carrying out a review of documents, researchers investigate written objects such as books, magazines, documents, regulations, minutes of meetings, diaries and so on. The document study was conducted to investigate written objects related to this research. Document review is also carried out on books that are related to research.

Data analysis techniques are carried out in conjunction with data collection, when entering the field with a grand tour and mini-tour question, namely by domain analysis. The next stage is to determine the focus, data collection techniques with a mini-tour question, data analysis is done by taxonomic analysis. Then in the selection stage, the questions used are structural questions, data analysis with compound analysis, and next is theme analysis. So the analysis is carried out interactively through four components where the four components are the cyclical process in this study. The four components are data reduction, data presentation, interpretation and inference data.

\section{Result and discussion}

\subsection{Profile of the graduate school of UIN Sunan Ampel Surabaya}

Postgraduate of UIN Sunan Ampel Surabaya was established in 1994. The history of the establishment of UIN Sunan Ampel Surabaya can be seen from several important decision chronologies as follows: (1) Decree of the Minister of Religion of the Republic of Indonesia No. 286 of 1994, concerning the permission of the organizer of the Dirasah Islamiyah Postgraduate Master program on August 1, 1994, (2) The Decree of the Director-General of Islamic Institution of the Ministry of Religion of the Republic of Indonesia No.E / 250 of 2001 concerning the permission of the organizer of the Postgraduate Doctoral Study Program (Dirasah Islamiyah) September 26, 2001, (3) Decree of the Director-General of Islamic Education No. Dj. I / 496/2007, regarding the permission of the organizers of the Master of 
Madrasah Ibtidaiyah (S2) Master program on December 17, 2007, (4) Decree of the DirectorGeneral of Islamic Education No. Dj. I / 197/2009 concerning the extension of the permission of the master and doctoral study program director Dirasah Islamiyah, April 14, 2009, (5) Decree of the Director-General of Islamic Education No. 2086 of 2013 concerning the transformation of concentration into a study program in the master's program, July 25, 2013, (6) Decree of the Director-General of Islamic Education No.3031 of 2017 concerning the extension of the permit to administer the Master of Madrasah Ibtidaiyah (S2) Master Program on May 31, 2017.

UIN Sunan Ampel Surabaya Postgraduate Education Priorities are: 1) Development of Islamic Traditions, 2) Development of change and evolution in the Islamic world, 3) Development of methodological abilities and their absorption, 4) Development of studies on the origin of Islamic traditions, 5) Scientific research, and 6) Studies on contemporary dynamics occurring in the Islamic world that are associated with classical heritage and modern development. The Director of the Postgraduate Program of UIN Sunan Ampel Surabaya for the 2018-2022 period was held by Prof. Dr. H. Aswadi, M.Ag., with a vision: "To become a center of excellence in Islamic studies (Islamic Studies) which has international competitiveness in 2021".

\subsection{Student profile}

Students of the Five Thousand Doctoral Scholarship Program UIN Sunan Ampel Surabaya have varied S1 and S2 educational backgrounds. Backgrounds of S1 education include Islamic Religious Education, Management of Islamic Education, Mathematics, Muamalah, Aqeedah Philosophy, Islamic Law, Muamalah Jinayah, Management Science, Economics, Interpretation of Hadith, Al-akhwal Syakhsiyah, Interpretation and Qur'anic Sciences, Comparison of mazhab, and Qadla. They come from public and private universities including, IAIN Jember, STAIN Ponorogo, IAIN Raden Intan Lampung, UIN Sunan Kalijaga, UIN Malang, IKAHA Tebuireng Jombang, UIN Sunan Ampel, STAIN Tulungagung, IAI Riyadlatul Mujahidin, UIN Sulthan Syarif Kasim Riau, ISID Gontor Ponorogo, STAI Alkhaziny, STAI Sunan Drajat, UIN Syarif Hidayatullah Jakarta, IAI Jakarta, STAIN Bukit Tinggi, Al-Azhar University, UNISMA Malang, and Kuliyah Dakwah Al-Islamiyah.

The educational backgrounds of the Masters are Sharia Economics, Arabic Language, Religious Studies and Conflict Resolution, Islamic Religious Education, Philosophy, Sharia Economic Law, Dirasah Islamiyah, Interpretation of Hadith, Islamic Education, Arabic, Alakhwal Syakhsiyah, Educational Management, Interpretation and Qur'anic Sciences, Islamic Economics, Philosophy, Ulumul Qur'an, Interdisciplinary Islamic Studies Social Work, Islamic Thought, Islamic Law, and Sharia. They came from universities including UGM, UIN Syarif Kasim Riau, University of Indonesia, Patimura University Ambon, UIN Sunan Ampel, IAIN Tulungagung, UIN Sunan Kalijaga, IAIN Jember, UIN Syarif Hidayatullah Jakarta, UIN Malang, Surabaya State University, STAI Al-Khaziny, IAIT Kediri, Erciyes University Turkey, and IAIN Imam Bonjol Padang.

\subsection{Featured program}

The purpose of the Doctoral Program at UIN Sunan Ampel Surabaya is to produce Muslim scholars who believe in and fear Allah SWT, have the spirit of Pancasila and have high scientific integrity. Be open, responsive to changes, progress, and development of knowledge and problems faced by the community, especially those related to the field of 
Islamic science. As experts in the field of Islamic science who are able to become research staff in the field of science. Have intellectual and moral integrity in accordance with the profession in the field of Islamic science studies. Having methodological abilities in carrying out Islamic studies, as well as being able to understand and analyze social and religious phenomena that develop in society. At present, UIN Sunan Ampel Surabaya has four doctoral programs, namely: Islamic Religious Education, Qur'anic Studies and Interpretation, Islamic Economics, and Islamic Studies.

The flagship program for the Doctoral program (S3) is the Islamic Study Program. Based on BAN-PT Decree No. 006 / SK / BAN-PT / Akred / D / I / 2014 dated January 9, 2014, Islamic Doctoral Study Program/Dirasah Islamiyah, State Islamic University of Sunan Ampel is accredited with Accreditation rank B. Accreditation of Postgraduate Lecturers of UIN Sunan Ampel Surabaya consists of 145 people, 34 holds a professor, 15 professors are permanent lecturers and supervisors in Postgraduate. They are professors and doctors graduated from well-known universities both at home and abroad. Of 129 Students of the Five Thousand Doctoral Program at UIN Sunan Ampel Surabaya, there were 69 students taking the Flagship Study Program namely Islamic Studies. This number is the highest compared to other study programs.

\subsection{Strengths and weaknesses of student programs}

The 5,000 doctoral scholarship program students at UIN Sunan Ampel Surabaya have different backgrounds that reflect their strengths and weaknesses. Strengths of the 5000 doctoral scholarship program UIN Sunan Ampel Surabaya lies in their study backgrounds both S1 and S2 with a strong scientific tradition. They came from various well-known universities such as UGM, UIN Sultan Syarif Kasim Riau, University of Indonesia, Patimura University Ambon, UIN Sunan Ampel, UIN Sunan Kalijaga, UIN Syarif Hidayatullah Jakarta, UIN Malang, Surabaya State University, Erciyes University Turkey, Al-Azhar University Egypt and various UIN throughout Indonesia.

They are also lecturers in various universities both public and private who have experience in the field and even have those who have positions in their workplaces such as Head of Study Program, Chairperson, Kopertis coordinator lecturer, and other positions. Surabaya which is a very religious area located in East Java with a variety of cultural features, supported by pesantren as a power of subculture, also gives its color in forming good academic traditions for the scientific development of students participating in the program.

While their weaknesses include being less proficient in mastering foreign languages, especially English, so that it affects the use of scientific literature, their backgrounds come from distant regions, causing their concentration in learning to be disrupted because they have to share time with family, so as not to It is surprising that many of the students who graduate late are targeted by the Ministry of Religion, namely 3 years.

\subsection{Planning}

Data on the participants of the Five Thousand Doctoral Scholarship program at UIN Sunan Ampel Surabaya from the 2015/2016 Academic Year to the 2018/2019 academic year are as follows: 
Table 1. Data on participants for the 5000 doctoral program.

\begin{tabular}{clccccc}
\hline \multirow{2}{*}{ No } & Study Program & 2015 & 2016 & 2017 & 2018 & \multirow{2}{*}{ Total } \\
\cline { 3 - 5 } & & 10 & - & - & - & 10 \\
1 & Islamic Education & 5 & - & - & 10 & 15 \\
2 & Qur'anic Sciences and Exegesis & 5 & - & 18 & 12 & 35 \\
3 & Islamic Economics & 9 & 36 & 24 & - & 69 \\
4 & Islamic Sudies & 29 & 36 & 42 & 22 & 129 \\
\hline
\end{tabular}

As for the progress report, students receiving the Five Thousand Doctoral Scholarship program at UIN Sunan Ampel Surabaya from 2015 to 2018, are:

Table 2. Progress report of participants for the 5000 doctoral program.

\begin{tabular}{cccccccc}
\hline No & Academic Year & Total & Pass & $\begin{array}{c}\text { On } \\
\text { Guidance }\end{array}$ & $\begin{array}{c}\text { Proposal } \\
\text { Exam }\end{array}$ & $\begin{array}{c}\text { Theory } \\
100 \%\end{array}$ & $\begin{array}{c}\text { Theory }< \\
100 \%\end{array}$ \\
\hline 1 & $2015 / 2016$ & 29 & 3 & - & 17 & 9 & - \\
2 & $2016 / 2017$ & 36 & - & 7 & 22 & 7 & - \\
3 & $2017 / 2018$ & 42 & - & - & - & 42 & - \\
4 & $2018 / 2019$ & 22 & - & - & - & - & 22 \\
\hline
\end{tabular}

In terms of planning, the maximum timeframe for completing the $\mathrm{S}-3$ education set by the Ministry of Religion is 6 semesters. Data on the five thousand Doctoral Scholarship program participants at UIN Sunan Ampel Surabaya totaled 129 people. The first batch of students in 2015 was 29 people, out of these 3 people passed on time for 3 years (6 semesters), while the other 26 people were still in the process of theory, proposal examinations and dissertation guidance. Since they entered semester seven of the 2018/2019 academic year, they were required to pay themselves to complete their studies, because they had exceeded the time limit set by the Dictator.

Some reasons related to their inaccuracy in completing studies in 3 years (6 semesters) are because the 3 years were too fast and had difficulty finding examiners. On the other hand, they have a lot of things to complete such as research that requires a lot of time and funds, not to mention family issues that they have to take care of. According to them, the policy of study time which must be completed by students for 3 years must be reconsidered since there are still many students who cannot complete their studies on time. The addition of study time from 3 years to 3.5 years or 4 years seems to be a wise and appropriate step that must be immediately carried out by the DIKTIS as a policy holder.

\subsection{Implementation}

The purpose of the five thousand Doctoral Scholarship Program is to improve the quality and professionalism of lecturers and education staff within the Directorate General of Islamic Education as part of improving the quality, relevance, and competitiveness of Islamic higher education which is the direction of Government policy in national education. But in practice, this program is less attractive to PNS lecturers at PTKIN. At UIN Sunan Ampel Surabaya, the 5000 doctoral scholarship program is much sought after by lecturers from PTKIS lecturers, while UIN Sunan Ampel's lecturers and other PTKIN lecturers are less interested in joining the program on the grounds that the income they get is from basic salary, benefits lecturers, 
guiding students, guiding KKN, guiding and testing thesis, and lecturer certification allowance is far greater than the Five Thousand Doctoral scholarship program.

If they join the Five Thousand Doctor program, their benefits will be lost, they will only get a basic salary, while they will not get certification and other income. They are more interested in continuing their studies at their own expense or through Education Financing Assistance. During this time the acceptance of five thousand doctoral scholarship program students income of Rp. 4,000,000 per month with the allocation of living expenses, books, domicile, and research. This amount is felt to be inadequate, not comparable to the needs of S3 students who are married with various needs.

Moreover, burdened with research funding and reference books allocated from the budget. With such conditions, a breakthrough needs to be made so that PNS lecturers at PTKIN become more interested in participating in the five thousand Doctoral scholarship program. Some things to think about include increasing the nominal amount of the scholarship beyond the salary and benefits they have been getting so far. In order to avoid a gap between the study program's needs and what is provided by the Ministry of Religion, another solution, as stated by Prof. Dr. H. M. Ridwan Nasir, MA., Chancellor of UIN Sunan Ampel period (2000-2008) and Director of Postgraduate period 2009-2013, is to revive the nursery of lecturers. With lecturers' nurseries, the program participants are mostly internal, so that they are in line with what is needed by universities with the formation given by the government.

UIN Sunan Ampel Surabaya in running a 5000 doctoral scholarship program, only as an extension of the Diktis. Participant criteria, requirements and others have been set by the Dictator, so it is not surprising that most participants from outside are very many and do not prioritize lecturers from the organizing Higher Education. Especially since 2018, there is a policy that UIN lecturers who want to take the five thousand Doctoral scholarship program may not take scholarships at their place of work but must study at other tertiary institutions. The problem is what if the department or study program only exists in the College where he works.

Doctoral programs that are most needed in the workplace Students participating in the 5000 doctoral scholarship programs include Islamic Economics, Islamic Philosophy, Islamic Religious Education, Hadith, Philosophy, Mathematics, English, Communication, Islamic Economics, Islamic Accounting, Islamic Finance, and Islamic Business. Most of the five thousand Doctoral scholarship program students at UIN Sunan Ampel Surabaya have taken the needed study programs at their workplaces, but there are also those who take study programs besides what is needed, such as at work requires a hadith doctor instead of taking Dirasat Islamiyah, at work requiring a Doctor of Philosophy, mathematics and English instead take the Dirasah Islamiyah study program, with the reason that there is no quota given and is not linear with the previous level of education.

\section{Conclusions}

In terms of planning the study, the period is limited to only three years, the majority of Program students cannot finish it on time. Of the 29 final program students, who can finish on time only 3 people, they think the time is very less, especially related to the completion of research and dissertation. In terms of implementation, enthusiasts of the Five Thousand Doctoral Scholarship Program at UIN Sunan Ampel Surabaya are in great demand by lecturers with lecturer backgrounds at Private Universities (PTKIS). Full scholarship program in its 
implementation both from the criteria and requirements of prospective recipients is considered appropriate with an easy procedure because it is done online, strict selection, open with strict monitoring. Postgraduate UIN Sunan Ampel Surabaya has an excellent Doctoral program, Dirosah Islamiyah, which develops Islamic studies with an interdisciplinary approach and social theories with an emphasis on contemporary issues such as human rights, gender, and democracy. The most needed doctor at the moment at UIN Sunan Ampel Surabaya is the Doctor of Sharia Economics. For now, there are four lecturers at UIN Sunan Ampel Surabaya who take doctoral study programs in the field of sharia economics. Of the four people who took the five thousand doctoral scholarship program, only one person. The Ministry of Religion needs to make special efforts so that the scholarship program is much sought after by lecturers not only from Private Islamic Religious Colleges but from State Islamic Religious Colleges. The strategy taken is for example by allowing Civil Servants lecturers to participate in a scholarship program, taking into account their income from scholarships not less than the basic salary, performance allowances, and other benefits they get daily.

Acknowledgements. The author would like to thank all those who contributed to this research. First, to the Head of the Center for Religion and Religious Education, Research and Development Agency, Ministry of Religion of the Republic of Indonesia. Second, to the Director of the Postgraduate Program of UIN Sunan Ampel Surabaya who has permitted for the author to research on this campus, all the Lecturers and Professors at the Postgraduate School of UIN Sunan Ampel Surabaya, education staff and all 5000 doctoral students, who have provided data and information to the author. Hopefully, this research will be useful for the development of the 5000 doctoral scholarship program going forward.

\section{References}

[1] George R Terry, 2003. Principles of Management, Bumi Aksara, Jakarta.

[2] John M. Echols and Hassan Shadily, 1995. Indonesian English Dictionary, PT. Gramedia Pustaka Utama, Jakarta.

[3] Mahdi bin Ibrahim, 1997. Amanah in Management, Pustaka Al Kautsar, Jakarta.

[4] Robbin and Coulter, 2007. Management (eighth edition), PT Index, Jakarta.

[5] Sondang P Siagian, 1990. Philosophy of Administration, CV Mas Agung, Jakarta.

[6] Sugiono, 2012. Mixed Research Methods, Alfabeta, Bandung.

[7] Sujarto, Djoko. 1986. "Perencanaan Kota Baru". Bandung: Penerbit Institut Teknologi Bandung (ITB). 